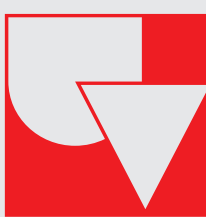

Universidad del Valle

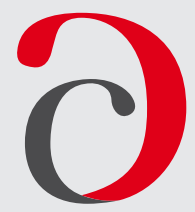

Cuadernos de Administración
Journal of Management

Print ISSN: 0120-4645 / E-ISSN: 2256-5078 / Short name: cuad.adm.

Pages: 53-63 / Vol: 36 / Issue: 66 / Jan. - Apr. 2020

Faculty of Administration Sciences / Universidad del Valle /

Cali - Colombia

\title{
Trust as a mechanism to improve organizational performance
}

\section{La Confianza como un mecanismo para mejorar el desempeño en las organizaciones}

\section{${ }^{1}$ Guillermo Buenaventura-VeraD}

Full-time Professor, Accounting and Finance Department, School of Administration and Economics Universidad Icesi, Cali, Colombia. e-mail: buenver@icesi.edu.co

\section{Juan Antonio Gudziol-Vidal (D)}

CEO, East Pacific Academy, Cali, Colombia. e-mail: jgudziol25@gmail.com

\author{
Article of Scientific and Technological Research \\ Submitted: 30/04/2019 \\ Reviewed: 18/07/2019 \\ Accepted: 07/03/2020 \\ Thematic lines: Administration and Organizations \\ JEL classification: M12, M54, 015 \\ DOI: https://doi.org/10.25100/cdea.v36i66.7897
}

\begin{abstract}
This paper designs and contrasts a relational model between the trust of collaborators in organizations and the performance of the company, mediated by the organizational commitment to learning and the commitment of employees to the company. As key objectives, a double mediation model is tested in the relationship between intra-organizational trust and the firm's performance, through the organization's commitment to learning and the commitment of collaborators to the company. Using a 31-item survey, the goodness of the model was evaluated with a sample of 161 individuals from different organizations in southwestern Colombia. The proposed model and its respective adjustment indexes were tested by using structural equations (SEM) modeling and the AMOS software package. The results demonstrate the empirical evidence, by statistically contrasting the model that posits the existence of relationships among the variables of the relational model. The findings made it possible to set parameters for the management of competencies and skills that contribute to the improvement of organizational performance.
\end{abstract}

Keywords: Trust, Organizations, Performance, Organizational learning, Commitment.

\section{Resumen}

En este trabajo se diseña y contrasta un modelo relacional entre la confianza del colaborador en la organización y el desempeño de la compañía mediado por el compromiso organizacional con el aprendizaje y el compromiso de los empleados con la empresa. Como objetivos clave, se prueba un modelo de doble mediación en la relación de la confianza intra-organizacional y el desempeño de las firmas, a través del compromiso de la organización con el aprendizaje y del compromiso de los colaboradores con la empresa. Utilizando una encuesta de 31 ítems, se evaluó la bondad del modelo en una muestra de 161 individuos de diferentes organizaciones en la región suroccidental de Colombia. Para la validación del modelo propuesto y sus respectivos índices de ajuste fue utilizado el modelamiento a través de ecuaciones estructurales (SEM) y el paquete de software AMOS. Los resultados demuestran la evidencia empírica,

Chemical Engineer, Universidad del Valle, Colombia, Doctor in Business Management, Universitat de Valencia, Spain.

2 Business Administrator, Universidad del Valle, Colombia, Doctor in Business Management, Universitat de Valencia, Valencia, Spain. 
al contrastar estadísticamente el modelo que planteaba relaciones entre las variables del modelo relacional. Los hallazgos permitieron establecer parámetros para la gestión de competencias y habilidades que aportan a la mejora del desempeño de las organizaciones.

Palabras clave: Confianza, Organizaciones, Desempeño, Aprendizaje organizacional, Compromiso.

\section{Introduction}

Trust is the predisposition of an individual to assume a position of vulnerability in the face of the other's actions while expecting a positive behavior from the latter (Ferrin, Bligh, and Kohles, 2008). Trust is one of the main sources of social collaboration, an aspect that attests to the ability to work together, leading to the achievement of a goal or objective (Gordon, 2006).

Furthermore, trust is conceived as a necessary element of cohesion that provides consistency to social structures (García and Real, 2013), evidencing its importance for interpersonal relationships in a work team and impacting directly on the performance of an organization. Nevertheless, the trust a manager demonstrates towards his employees is perceived by the latter as a sign of organizational support, thereby impacting on the need to become involved in the development of a learning culture (García and Real, 2013).

The positive relationship between Commitment and Trust (Guinalíu and Jordan, 2016), and between Commitment and Organizational Commitment to Learning (García and Real, 2013), allow us to consider that cultivating the trust of employees in the company is a determining factor to impact performance positively. Guinalíu and Jordán (2016), in their research on building trust in virtual work teams, validate the hypotheses that link empathy, justice and leadership style with trusting the leader.

The organization's ability to learn and commitment to learning impact innovation directly (Alegre and Chiva, 2008). Likewise, cultural factors, tolerance to error, decentralization of decision-making, and social relations will positively influence organizational learning (Hult, Hurley and Knight, 2004; Bueno, Ordoñez and
Salmador, 2004; Koc and Ceylan, 2007) and organizational learning will positively influence the firm's performance (Alegre and Chiva, 2008; Fernández, Alegre and Chiva, 2012).

On the other hand, trust among collaborators positively affects organizational learning (Delgado and Castañeda, 2011), and the positive relationship between organizational learning and group and organizational performance has also been widely discussed and established (Fiol and Lyles, 1985; Dogson, 1993; Slater and Narver, 1995; Garvin, 1994; Bontis, Crossan, and Hulland, 2002; Gudziol, 2015).

Hence, the positive relationship between the trust of team members in the company (TRUST), the commitment of collaborators to their work (COMM) and the Organizational Commitment to Learning (CAO) constitute a highly relevant relational mechanism for any organization to perform well. This work is oriented in this direction and establishes a relational model between the trust of collaborators and the organization and the performance of the company, involving two vital mediators, as are organizational learning and the commitment of collaborators to their company.

\section{Theoretical framework}

In the rapid pace of transformation in the context of industries, which has forced many organizations to become increasingly competitive today (Lynn, Laosirihongthong, and Chan, 2006), trust appears to be a paramount element in achieving this goal.

Trust, referring to the assumption that a person holds about the likelihood that the future actions of others will be beneficial or at least not harmful to one's own interests (Schwepker and Good, 2012 operational, and research spotlight on relational building and retention in recent years, practitioners must balance this vision with commonly critical selling practices and needs (i.e., obtain sales quota while building and retaining customer relationships), or to the expectation of a person or a company to behave in an ethically justifiable manner, that is, the other person will create an analysis that 
describes this action as morally correct (Schwepker and Good, 2012 operational, and research spotlight on relational building and retention in recent years, practitioners must balance this vision with commonly critical selling practices and needs (i.e., obtain sales quota while building and retaining customer relationships). It is the establishing of perceptions and attitudes as a whole and a representation of accumulated knowledge and experiences with the other party (Alsaad, Mohamad, and Ismail, 2017).

An organization's performance is a consequence of having had a good effect on trust within the work team (Jain, Khalil, Johnston, and Cheng, 2014). Likewise, both in family and non-family companies, the organizational effectiveness of suppliers and the trust in the buyer appear as positive predictors of performance for these companies (Stanley and McDowell, 2014).

In a workgroup, trust generates an atmosphere of security where there is no fear of opportunistic behavior or fraudulent use of information (Camelo, García, Sousa, and Valle, 2011). Therefore, it can then be asserted that trust management is the key element in ensuring a competitive organization capable of producing extraordinary results (Camelo et al., 2011). Organizations are no longer based on power but trust. For instance, there is a positive relationship between an organization's sales performance and the trust that exists between the working team and the company (Schwepker and Good, 2012)operational, and research spotlight on relational building and retention in recent years, practitioners must balance this vision with commonly critical selling practices and needs (i.e., obtain sales quota while building and retaining customer relationships.

On the other hand, organizational learning is based on the commitment to learning, the shared vision and the open mindset established by senior management. The above three dimensions of learning relate to the commitment of the collaborator, i.e., people who are more committed to themselves and the organization are more likely to contribute positively to teamwork and organizational outcomes (Lynn et al., 2006).
Individual learning and team learning bear positive effects on organizational learning, as individuals and teams donate their knowledge and experiences to improve the organization (Lynn et al., 2006).

In organizations, a direct relationship exists between employee engagement, trust and organizational behavior in the opinions of supervisors in each area of some companies taken for sample, as the study by Achtenhagen (2016) has demonstrated. Commitment also plays an important role when implementing actions and it reflects either collaborators' affection towards the organization or their moral obligation to remain in the organization (Cabrera and Urbiola, 2012).

\section{Methodology}

\subsection{Presentation of the Model}

Organizations are work teams' systems. It is important to analyze the relationship between trust and performance, from the perspective of team members in respect of their leaders and the company, through variables that are key to development and evolution. Such catalytic variables are CAO and COMM (García and Real, 2013estudiamos lu00a1a influencia del com-promiso afectivo de los empleados percibido por el directivo, tanto sobre su nivel de confianza, como sobre la capacidad de aprendizaje organizativo (CAO). A relational model between the variables TRUST, COMM, CAO and Company Performance (PERFORM) is based on the hypotheses developed below.

\subsection{Development of hypotheses}

Trust creates an atmosphere of security in workgroups and the organization, where there is no fear of opportunistic behavior or fraudulent use of information (Camelo et al., 2011), which fosters healthy communication, a key component in the organization's commitment to learning. On the other hand, as people bring and share their knowledge, skills, and experiences with other individuals in a team, it becomes possible for individual and team learning to 
occur (Lynn et al., 2006). This is explained because when people feel safe about their environment and relationships with their peers, they tend to give their knowledge and time to share it, enabling the group to learn through individual knowledge and experience. Likewise, such a sense of safety gives way to the willingness to learn, grow, and contribute, and so the company manages to have its training programs assimilated and obtains the desired results. Hence, the following hypothesis is posted:

Hypothesis 1: Collaborators' trust in the organization (TRUST) is positively associated with the organization's commitment to learning (CAO).

According to Tamer and Derelİ (2014), when employees trust their managers and peers, they are more likely to hold positive attitudes towards the organization and show greater commitment, both normatively and affectively. Thus, committed employees tend to stay in the organization (Tamer and Derelí, 2014) and do an extra effort. Moreover, they exploit their proactivity to achieve the company's goals, while cultivating a behavior to look after the organization's assets. These attitudes form a layer of protection against bad practices and, in turn, promote the trust of managers towards their employees. Therefore, the need to link the generation of trust with commitment is recognized, therefore:

Hypothesis 2: Trust in the organization (TRUST) is positively associated with collaborators' engagement (COMM).

Competitive advantages are strengthened when the organization strengthens its knowledge and experience, thus allowing its strategic advantage to develop as well, improving process interoperability by reduced agency costs and transaction costs. Furthermore, when a company gains competitive advantages, it can conceive and implement strategies that improve its effectiveness and efficiency in the future. Such an increase in efficiency and efficiency, together with knowledge and experience, promotes higher sales volumes and market share (e.g. Jain et al., 2014). Knowledge and experience shape this key ability to compete, which the company gains when it is positively willing to commit to learning and supports putting forth the following hypothesis:

Hypothesis 3: The organization's degree of commitment to learning (CAO) positively affects the performance of the organization (PERFORM).

In the 1970s and 1980s, commitment as such emerged as a key factor in the relationship between individuals and organizations. It was argued that the existence of an individual's commitment to the organization acts as an engine of organizational performance (for example, Krishnaveni and Ramkumar, 2008). This led to bestowing higher importance on commitment as seen in the hypothesis and allows us to associate the attitudes and behavior of individuals, as generated by their commitment, with the actual performance of the organization to which they belong. This relationship makes it possible to formulate the following hypothesis:

Hypothesis 4: Collaborators' commitment to the organization (COMM) is positively associated with the organization's performance (PERFORM).

An intangible asset of a company cannot be easily copied; it is attained with a lot of effort and time. An asset of great value is the close relationships between partners from different levels developed through trust, which reduce the perception of vulnerability and help in the construction of healthy and collaborative relationships (Jain et al., 2014), leading directly to the formulation of the hypothesis:

Hypothesis 5: the trust of collaborators on the Organization (TRUST) positively affects the performance of the company (PERFORM).

Mossholder, Richardson, and Settoon(2011) believe that a close relationship between employees and the organization encourages social behaviors such as knowledge sharing, peer support, and collaboration. Likewise, Allen and Mayer (1996) highlight the fact that employees' commitment to the organization creates high support for the organization's objectives. Employees who are highly committed to the firm can fully relate to their organization and participate actively in their workplace (Tamer and Derelí, 2014). 
Figure 1. Proposed model and relationship hypotheses

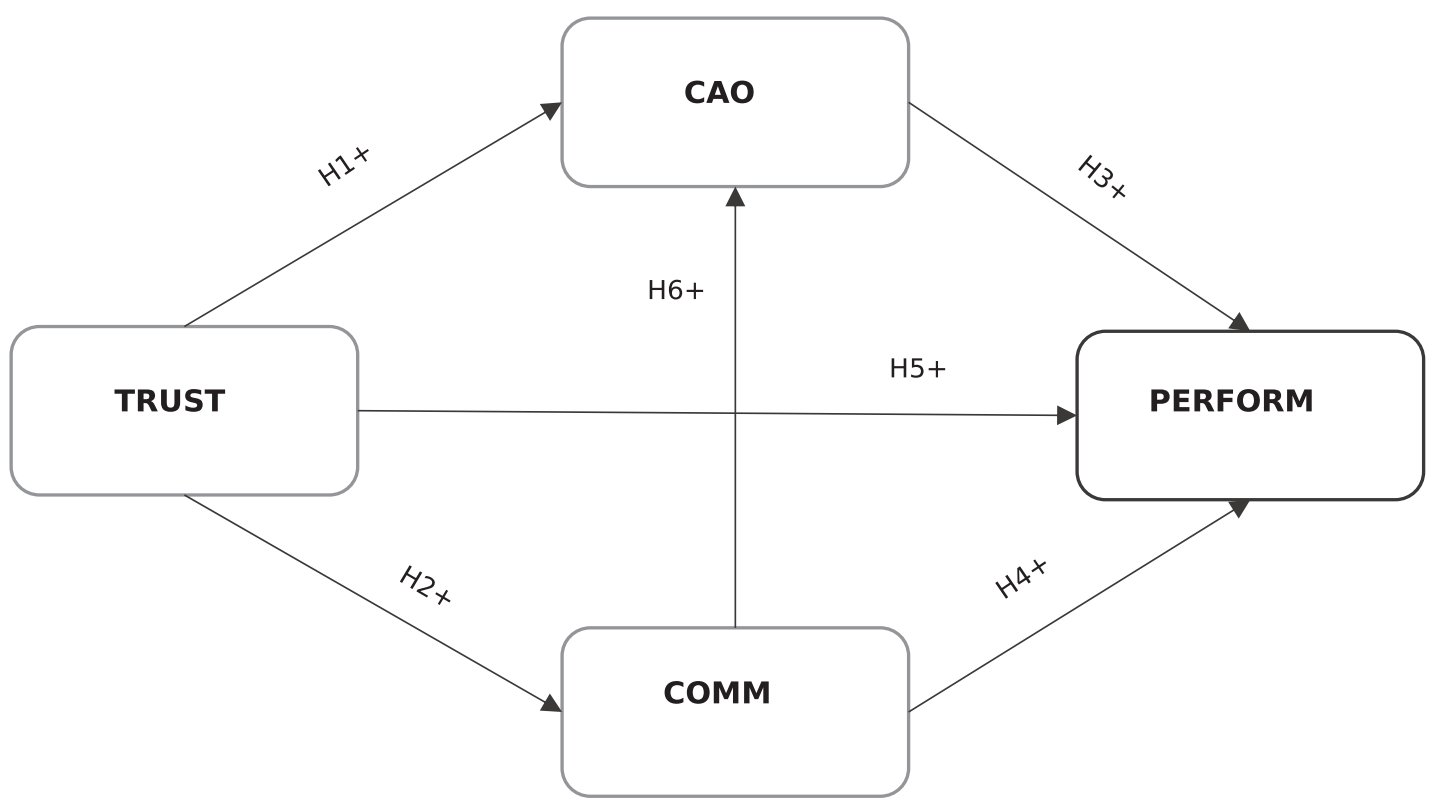

Source: Authors' own elaboration.

Thelinkbetween commitmenttoknowledge sharing and employee participation, and the elements of the organization's commitment to learning, is the basis to formulate the following hypothesis:

Hypothesis 6: Employee commitment to the organization (COMM) is positively related to the organization's commitment to learning $(\mathrm{CAO})$.

Figure 1 outlines the hypotheses raised.

\subsection{The measuring instrument to contrast the hypotheses}

The measurements of the variables in the model, all variables directly unobservable (latent variables), were carried out through a survey structured by the scales that best adapt to the model and chosen from the literature.

We sought affinity with the variables that are planned in the model, without neglecting their simplicity, to avoid overloading the questionnaire, so that it would be answered with the same degree of attention all the way through. Table 1 shows the sources of the selected scales.

The scale for the COMM variable is nineitem and one-dimensional, and corresponds to the development by Mowday et al., and used by Cabrera and Urbiola (2012). The scale selected to measure CAO was taken from the dimension "Commitment of the Organization to Learning", it is six-item, the constituent dimension of the variable "Learning", used by Lynn et al. (2006). The TRUST variable was measured with the seven-item "Trust in Organization" scale used by Schwepker and Good (2012). The PERFORM variable was measured with the scale employed by Schwepker and Good (2012), with nine items, corresponding to the variable "Operational performance" in his study. The ultimate questionnaire was a 31-item document on study variables (Table 2) and beyond the questions on control variables.

The survey was structured using a 7-point Likert scale (7: Totally Agree, 1: Totally disagree) to establish the degree of agreement or disagreement of the respondent regarding the statements in each item (Morales, Urosa and Blanco, 1993). 


\begin{tabular}{|c|c|c|c|}
\hline Variable & Source & Authors & Year \\
\hline COMM & $\begin{array}{l}\text { "Shorted Organizational Commitment Quetionaire } \\
\text { (SOCQ), in: "Compromiso organizacional y estrés } \\
\text { ocupacional: Estudio de caso en una empresa de } \\
\text { distribución y venta de gas LP en Costa Rica" }\end{array}$ & $\begin{array}{l}\text { Mowday et al. In Cabrera } \\
\text { Lazarini and Urbiola Solís }\end{array}$ & 2012 \\
\hline $\mathrm{CAO}$ & $\begin{array}{l}\text { "A case of study of learning in a Thai } \\
\text { manufacturing organization" }\end{array}$ & Lynn et al. & 2006 \\
\hline PERFORM & $\begin{array}{l}\text { "Inter-firm dependence, inter-firm trust, and } \\
\text { operational performance: The mediating effect of } \\
\text { e-business integration" }\end{array}$ & Shi and Liao & 2015 \\
\hline TRUST & $\begin{array}{c}\text { "Sales Quotas: Unintended Consequences on Trust } \\
\text { in Organization, Customer-Oriented Selling, and } \\
\text { Sales Performance" }\end{array}$ & Schwepker and Good & 2012 \\
\hline
\end{tabular}

\begin{tabular}{|c|c|}
\hline & Table 2. Questionnaire scales \\
\hline & Commitment scale, COMM \\
\hline 1 & I am willing to go above and beyond what is normally expected to support the success of the organization \\
\hline 2 & I speak of this organization to my friends as a great organization for which I work \\
\hline 3 & I would accept almost any type of job to continue in this organization \\
\hline 4 & I find that my values and those of the organization are very similar \\
\hline 5 & I am very proud to tell others that I am part of this organization \\
\hline 6 & This organization truly inspires the best of me in terms of job performance \\
\hline 7 & I am very happy to have chosen to work in this organization compared to other \\
\hline 8 & I really care about the fate of this organization \\
\hline 9 & To work, for me this is the best of all possible organizations \\
\hline & Organizational commitment to learning scale, CAO \\
\hline 10 & The manager agrees that the ability of our business unit to learn is the key to our competitive advantage \\
\hline 11 & $\begin{array}{l}\text { The experiences and ideas provided by external sources (advisors, clients, practitioners, etc.) are considered as a useful } \\
\text { instrument in the learning of the company }\end{array}$ \\
\hline 12 & The feeling in the management of the company is that the learning of the employees is an investment and not an expense \\
\hline 13 & Learning in the organization is seen as a basic key necessary to guarantee the survival of the company \\
\hline 14 & In this company, innovative ideas that work are rewarded \\
\hline 15 & The collective wisdom in this company establishes that once we stop learning, we endanger our future \\
\hline & Organizational performance scale, PERFORMANCE \\
\hline 16 & In the last three years, the quality of the products or services of the company where I work have improved \\
\hline 17 & In the last three years, the commercial value of the company where I work has increased \\
\hline 18 & In the last three years, the efficiency of the delivery of products or services has increased \\
\hline 19 & In the last three years, the time of production operations of the company where I work has been reduced \\
\hline 20 & The company where I work is able to respond quickly to customer requests \\
\hline 21 & In the last three years, there has been a growth in sales revenue in the company where I work \\
\hline
\end{tabular}




\begin{tabular}{|l|l|}
\hline 22 & In the last three years, there has been an increase in market share in the company where I work \\
\hline 23 & In the last three years, the productivity of employees in the company where I work has improved \\
\hline 24 & The company where I work has a great capacity to attract new clients \\
\hline 25 & I think my employer has high integrity \\
\hline 26 & The treatment I receive from the company is always fair and equitable \\
\hline 27 & My employer is not always honest and truthful \\
\hline 28 & Overall, I think my employer's intentions are good \\
\hline 29 & I don't think my employer treats me fairly \\
\hline 30 & My employer is open and frank with me \\
\hline 31 & I'm not sure I fully trust my employer \\
\hline &
\end{tabular}

\begin{tabular}{|c|c|c|c|c|c|c|c|c|c|c|}
\hline Hipothesis & H1 & H2 & H3 & H4 & H5 & H6 & y2/df & TLI & CFI & RMSA \\
\hline Standarized Coefficient & 0,28 & 0,85 & 0,65 & 0,15 & 0,24 & 0,32 & \multirow{2}{*}{2,6} & \multirow{2}{*}{0,92} & \multirow{2}{*}{0,94} & \multirow{2}{*}{0,078} \\
\hline Statisitical Significance & ** & $* * * *$ & $* * * *$ & ** & $* * *$ & $* * *$ & & & & \\
\hline
\end{tabular}

\subsection{Sample and application of the contrast instrument}

To calculate the sample size, we used the optimal sample size:

$$
n=\frac{N * Z^{2} * p * q}{d^{2} *(N-1)+Z^{2} * p * q}
$$

For a known population of 300 exporting companies in Valle del Cauca, which results in 131 as the optimal sample size (Hernández, Fernández, and Baptista, 2014; Otzen and Manterola, 2017), and a confidence level $\mathrm{Z}=$ $95 \%$, a maximum acceptable error of $5 \%$, $\mathrm{p}=0.5$ and $\mathrm{q}=0.5-$ maximum variance. In order to carry out the sampling, 300 physical questionnaires were sent out, which should be answered by the managers responsible for the export area of their company holding a professional degree. Of the 187 questionnaires that returned, 161 were valid, which improved accuracy by having a sample size larger than required. The Structural Equations Modeling (SEM) methodology was used with IBM's AMOS 23 software, following the procedures and indicators of this technique (Bollen, 1989).

\section{Results}

\subsection{Results of fieldwork}

As can be seen in Table 3, the model's fit more than meets the acceptable minimums for the proposed factors $\left(\psi^{2} / \mathrm{df}, \mathrm{TLI}, \mathrm{CFI}\right)$ while the RMSA is at an acceptable limit.

The indexes of the goodness of fit examined for the SEM-contrasted model were based on those employed in the literature and mentioned by Buenaventura-Vera (2017):

"Chi-square index on degrees of freedom $\psi^{2} / \mathrm{df}$. This measures of the centrality of the distribution (chi-square), against which variances are compared. For Marsh and Hocevar (1985), values between 2 and 5 are reasonably acceptable."

"RMSEA (Mean Squared Error of Approach). It presents the same measurement trend as the previous parameter but considers the size of the sample. Values above 0.10 are unacceptable, whereas values below or equal to 0.10 are acceptable, while those below 0.080 are satisfactory, and as very satisfactory are regarded values below 0.06 (Brown and Cudeck, 1993). 
Figure 2. Model analysis results by SEM

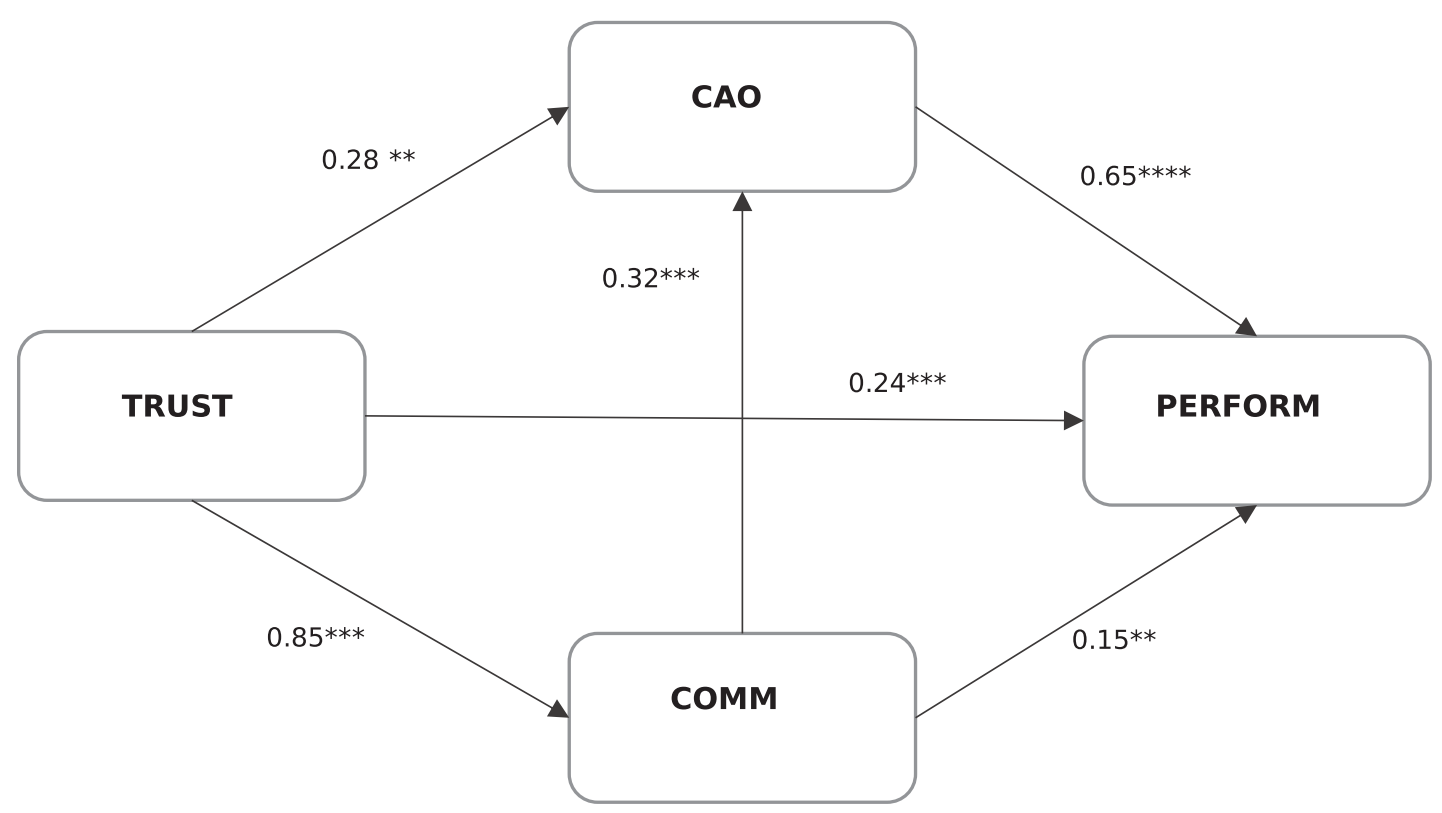

Source: Authors' own elaboration.

TLI, CFI (Turker-Lewis Index, Goodness of Fit Index). Those are indicators of the relationship of centralities (eccentricities complements) between the optimal model and the original model. They should, in principle, exceed 0.50, although there is no fixed lower limit, the closer to 1.0, the better (Bentler and Bonett, 1980; Bollen, 1989; Bentler, 1990; Buenaventura-Vera, 2017).

As can be seen in Table 3, the model's fit more than meets the acceptable minimums for the proposed factors $\left(\psi^{2} / \mathrm{df}, \mathrm{TLI}, \mathrm{CFI}\right)$ while the RMSA is at an acceptable limit. This makes it possible to accept the model for examining compliance with the proposed hypotheses.

However, the statistical significance of the relationships among the latent variables was above $95 \%$ in all cases, with positive coefficients, as shown in Table 3 and Table 4 , thereby validating the hypothesis of the model established in this study.

\section{Discussion}

The findings of the study can be summarized in the following statements that validate all hypotheses raised (Figure 2).

\begin{tabular}{|c|c|c|}
\hline \multicolumn{3}{|c|}{ Table 4. Significance Intervals } \\
\hline Probability & Significance & Symbol \\
\hline $\mathrm{P}<0.10$ & $10 \%$ & $*$ \\
\hline $\mathrm{P}<0.05$ & $5 \%$ & $* *$ \\
\hline $\mathrm{P}<0.01$ & $1 \%$ & $* * *$ \\
\hline $\mathrm{P}<0.001$ & $0.1 \%$ & $* * *$ \\
\hline \multicolumn{2}{|c|}{ Source: Authors' own elaboration. } \\
\hline
\end{tabular}

H1: There is a positive and significant relationship between Collaborators' Trust (TRUST) and Organizational Learning Capability (CAO).

H2: There is a positive and significant relationship between Collaborators' Trust in their company (TRUST) and their commitment to their work (COMM).

H3: There is a positive and significant relationship between Organizational Learning Capability (CAO) and Company Performance (PERFORMANCE).

H4: There is a positive and significant relationship between collaborators' commitment (COMM) to their work and the performance of the company (PERFORMANCE). 
H5: There is a positive and significant relationship between Collaborators' Trust (TURST) and Company Performance (PERFORMANCE).

H6: There is a positive and significant relationship between Collaborators Commitment (COMM) to their work and Organizational Learning Capability (CAO).

\section{Conclusions and final comments}

The model proposed in this research has positively contrasted the relationships the initial model put forth, attesting to a positive relationship between collective performance and trust, and between these and CAO and individual commitment. In other words, trust did prove to be a determining factor in and originator of a company's good performance.

This study makes a significant academic contribution, as it has shed light on a mechanism conducive to optimal performance in organizations.

This provides business leaders and organizations themselves with opportunities to increase business value. Within the business, social and cultural fields the need is reaffirmed to develop greater trust at all levels of the organization in order to enhance its performance. Especially in Latin countries, where the cultural balance leans towards distrust, a government program to rescue trust (TRUST) would have a positive and strong economic impact.

In the future, it would be appropriate to validate the model in a more robust manner, for which the sample should be broader and, in the process, take into account:

Taking a sample of more uniform organizations. Taking a similar sector or organizational type.

Carrying out a longitudinal study to corroborate the model at different times of the economy and the company.

\section{Conflict of interest}

The authors declare no conflict of interest.

\section{Source of Financing}

This research was sponsored by the Faculty of Administration and Economics of the Universidad Icesi through the investment groups "Inversión, Finaciación y Control" (COL0012168) and "Competitividad y Mercadeo en las Organizaciones" (COL0007426), both classified in category A1 Colciencias.

\section{References}

Achtenhagen, L., \& Brundin, E. (2016). Entrepreneurship and SME Management Across Africa. Context, Challenges, Cases. (L. Achtenhagen, \& E. Brundin, Eds.) Singapore: Springer Singapore. https://doi. org/10.1007/978-981-10-1727-8

Alegre, J., \& Chiva, R. (2008). Assessing the impact of organizational learning capability on product innovation performance: An empirical test. Technovation, 28(6), 315-326. https://doi. org/10.1016/j.technovation.2007.09.003

Allen, N. J., \& Meyer, J. P. (1996). Affective, Continuance, and Normative Commitment to the Organization: An Examination of Construct Validity. Journal of Vocational Behavior, 49(3), 252-276. https://doi.org/10.1006/jvbe.1996.0043

Alsaad, A., Mohamad, R., \& Ismail, N.-A. (2017). The moderating role of trust in business to business electronic commerce (B2B EC) adoption. Computers in Human Behavior, 68, 157-169. doi:https://doi.org/10.1016/j.chb.2016.11.040

Bentler, P. (1990). Comparative fit indexes in structural models. Psychological Bulletin, 107(2), 238-246. https://doi. org/10.1037/0033-2909.107.2.238

Bentler, P. M., \& Bonnet, D. G. (1980). Significance tests and goodness of fit in the analysis of covariance structures. Psychological Bulletin, 88(3), 588-606. $\quad$ https://psycnet.apa.org/ doi/10.1037/0033-2909.88.3.588

Bollen, K.A.(1989).StructuralEquationsWithLatent Variables. North Carolina: Wiley-Interscience Publication. doi: 10.1002/9781118619179

Bontis, N., Crossan, M. M., \& Hulland, J. (2002). Managing An Organizational Learning System By Aligning Stocks and Flows. Journal of Management Studies , 39(4), 437-439. https:// doi.org/10.1111/1467-6486.t01-1-00299 
Browne, M., \& Cudeck, R. (1993). Testing structural equation models. In B. K.A, \& L. J.S. (Eds.), Alternative Ways of Assessing Model Fit (pp. 136-162). Newbury Park, USA: SAGE Publications.

Buenaventura-Vera, G. (2017). The impact of leader self-efficacy on the characteristics of work teams. Intangible Capital, 13(4), 824-849. https://doi.org/10.3926/ic.938

Bueno, E., Ordoñez, P., \& Salmador, M.-P. (2004). Towards an integrative model of business, knowledge and organisational learning processes. International Journal of Technology Management, 27(6-7), 562-574. https://doi. org/10.1504/IJTM.2004.004902

Cabrera, J. J., \& Urbiola, A. E. (2012). Compromiso organizacional y estrés ocupacional: estudio de caso en una empresa de distribución y venta de gas lp en Costa Rica. Gestión Y Estrategia, 41, 15-28. http://gestionyestrategia.azc.uam.mx/ index.php/rge/article/view/85

Camelo, C., García, J., Sousa, E., \& Valle, R. (2011). The influence of human resource management on knowledge sharing and innovation in Spain: the mediating role of affective commitment. Journal The International Journal of Human Resource Management, 22(7), 1442 - 1463. https://doi.org/10.1080/09585192.2011.561960

Delgado, L.-E., \& Castañeda, D.-I. (2011). Relación entre el capital psicológico y la conducta de compartir conocimiento en el contexto del aprendizaje organizacional. Acta Colombiana de Psicología, 14(1), 61-70. Retrieved from http:// www.redalyc.org/articulo.oa?id $=79822602006$

Dodgson, M. (1993). Organizational Learning: A Review of Some Literatures. Organization Studies, 14(3), 375-394. https://doi.org/10.1177 \%2F017084069301400303

Fernández, A., Alegre, J., \& Chiva, R. (2012). Orientación Emprendedora, Capacidad de Aprendizaje Organizativo y Desempeño Innovador. Journal of Technology Management and Innovation, 7(2), 157-170. http://dx.doi. org/10.4067/S0718-27242012000200013

Ferrin, D. L., Bligh, M., \& Kohles, J. C. (2008). It takes two to tango: An interdependence analysis of the spiraling of perceived trustworthiness and cooperation in interpersonal and intergroup relationships. Organizational Behavior and Human Decision Processes, 107(2), 161-178. https://doi.org/10.1016/j.obhdp.2008.02.012

Fiol, C. M., \& Lyles, M. A. (1985). Organizational Learning. The Academy of Management Review, 10(4), 803-813. doi:10.2307/258048
García, J., \& Real, J. C. (2013). Confianza como consecuencia del compromiso percibido: Implicaciones sobre el aprendizaje y la innovación. Cuadernos de Gestión, 13(1), 95125. doi:10.5295/cdg.110282jg

Garvin, D. A. (1994). Building a learning organization. Boston: Harvard Business Review.

Gordon, S. (2006). Confianza, reciprocidad y asociatividad: Relación indispensable para el desempeño institucional? Esstudios Sociólogicos, 24(71), 397-421. Retrieved from https://www.jstor.org/stable/40421043

Gudziol, J.-A. (2015). Análisis del efecto del aprendizaje organizativo en el nivel de internacionalización de las empresas, y del papel mediador de la capacidad para competir internacionalmente $y$ de la flexibilidad estratégica. Valencia, España: Universitát de Valencia.

Guinalíu, M., \& Jordán, P. (2016). Building trust in the leader of virtual work teams Generación de confianza en el líder de equipos de trabajos virtuales. Spanish Journal of Marketing ESIC, 20(1), 58-70. https://doi.org/10.1016/j. reimke.2016.01.003

Hernández, R., Fernández, C., \& Baptista, P. (2014). Metodología de la Investigación. México D. F., México: McGraw-Hill.

Hult, T. M., Hurley, R. F., \& Knight, G. A. (2004). Innovativeness: Its antecedents and impact on business performance. Industrial Marketing Management, 33(5), 429-438. https://doi. org/10.1016/j.indmarman.2003.08.015

Jain, M., Khalil, S., Johnston, W. J., \& Cheng, J. M.-S. (2014). The performance implications of power-trust relationship: The moderating role of commitment in the supplier-retailer relationship. Industrial Marketing Management, 43(2), 312-321. $\quad$ https://doi.org/10.1016/j. indmarman.2013.09.001

Koc, T., \& Ceylan, C. (2007). Factors impacting the innovative capacity in large-scale companies. Technovation, 27(5), 105-114. https://doi. org/10.1016/j.technovation.2005.10.002

Krishnaven, R., \& Ramkumar, N. (2008). Revalidation Process for Established Instruments: A Case of Meyer and Allens Organizational Commitment Scale. The IUP Journal of Organizational Behavior, 7(2), 7-18. https://www.psgjcrm.com/journals/index.php/ jcrm/article/view/18

Lynn, L. K., Laosirihongthong, T., \& Chan, C. C. (2006). A Case Study Of Learning In A Thai 
manfacturing organization. Journal of Applied Business Research, 22(2), 49-60. https://doi. org/10.19030/jabr.v22i2.1435

Marsh, H., \& Hocevar, D. (1985). Application of confirmatory factor analysis to the study of self-concept: First- and higher-order factor models and their invariance across groups. Psychological Bulletin, 97(3), 562-582. https:// doi.org/10.1037/0033-2909.97.3.562

Morales , P., Urosa, B., \& Blanco, A. (1993). Construcción de escalas de actitudes tipo Likert. Una Guía práctica. Madrid, España: La Muralla.

Mossholder, K. W., Richardson, H. A., \& Settoon, R. P. (2011). Human resources system and helping in organization: A relational perspective. Academy of Management Review, 36(1), 33-52. doi:10.5465/AMR.2011.55662500

Otzen, T., \& Manterola, C. (2017). Técnicas de Muestreo sobre una Población a Estudio. International Journal of Morphology, 35(1), 227-232. http://dx.doi.org/10.4067/ S0717-95022017000100037

Schwepker, C. H., \& Good, D. J. (2012). Sales Quotas: Unintended Consequences on Trust in Organization, Customer-Oriented Selling, and Sales Performance. Journal of Marketing
Theory \& Practice, 20(4), 437-452. https://doi. org/10.2753/MTP1069-6679200406

Shi, X., \& Liao, Z. (2015). Inter-firm dependence, inter-firm trust, and operational performance: The mediating effect of e-business integration. Information \& Management, 52(8), 943-950. https://doi.org/10.1016/j.im.2015.06.010

Shi, X., \& Liao, Z. (2015). Inter-firm dependence, inter-firm trust, and operational performance: The mediating effect of e-business integration. Information \& Management, 52(8), 943-950. https://doi.org/10.1016/j.im.2015.06.010

Slater, S. F., \& Narver, J. C. (1995). Market Orientation and the Learning Organization. Journal of Marketing, 59(3), 63-74. doi:10.2307/1252120

Stanley, L. J., \& McDowell, W. (2014). The role of interorganizational trust and organizational efficacy in family and nonfamily firms. Journal of Family Business Strategy, 5(3), 264-275. https:/l doi.org/10.1016/j.jfbs.2013.07.001

Tamer, I., \& Dereli, B. (2014). The relationship between interpersonal trust, peer support and organizational commitment. Bireylerarasi Güven, Işgören Desteği ve Örgütsel Bağlilik Ilişkisi, 11(42), 175-196. https://doi.org/10.14783/ od.v11i42.5000065518

¿How to quote this article?

Buenaventura-Vera, G., \& Gudziol-Vidal, J. A. (2020). Trust as a mechanism to improve organizationalperformance. Cuadernos de Administración, 36(66), 53-63. https://doi.org/10.25100/cdea.v36i66.7897 